\title{
ALUMINOSILICATE SEDIMENT DISSOLUTION IN LIQUID RADIOACTIVE WASTE STORAGE FACILITIES
}

\author{
Kulagina T. A., Kulagin V. A. \\ Federal State Autonomous Educational Institution of Higher Education "Siberian Federal University", Krasnoyarsk, Russia
}

Article received on February 4, 2020

\begin{abstract}
The article deals with the extraction of insoluble sediments formed in storage tanks during long-term storage of liquid radioactive waste from spent nuclear fuel reprocessing. Results of a thermodynamic analysis are presented enabling to assess the structure of precipitation formed and to select most effective modes for thermal and hydrodynamic effects (cavitation technology) produced by liquid medium on eroded sediments. The paper presents the results of studies on the extraction of poorly soluble pulp components from storage tanks using cavitation technology.
\end{abstract}

Keywords: radioactive waste, waste from spent nuclear fuel reprocessing, cavitation technology, hardly soluble precipitation.

"Energy efficiency, energy saving, nuclear energy" is stated as a priority for engineering and technological development in the Russian Federation [1] corresponding to a critical technology: "Technologies for atomic energy, nuclear fuel cycle, safe management of radioactive waste and spent nuclear fuel”. The paper [2] focuses on the development of a regulatory framework in the field of RW management and nuclear and radiation safety until 2025. At the same time, discussed general trends for the development of nuclear power [3] do not draw particular attention to RW management, including the waste generated from spent nuclear fuel (SNF) reprocessing. The article [4] recognizes the need of accounting mutual interference between the development of the Unified State System of Radioactive Waste Management (USS RW) and the development of nuclear technologies constituting to Russian nuclear power complex (atomic energy and industrial complex, AEIC) involving nuclear fuel cycle and nuclear power.
To date, nuclear power industries all around the world have faced challenges associated with the processing of high-level waste accumulated over the last 50 years. Practice has shown that long-term storage of liquid waste leads to the accumulation of solid sediment in the storage tanks - pulp based on sodium hydroaluminosilicates formed during mixing and homogenization of liquid alkaline ILW [5]. Exactly this waste form is believed to be most challenging in terms of its processing and conditioning. Chemical methods are most commonly used to address this challenge by dissolving and extracting these sediments. However, these methods are characterized with some important disadvantages, since their application results in a decreasing corrosion resistance of storage facilities.

Along with imposing stricter norms and rules regulating RW management and the development of long-term planning tools allowing to consider these mutual influences [4], it is necessary to use new technologies the feasibility of which has been 
demonstrated by the scientific community. Experience gained in this field suggests that cavitation technology [8] based on thermohydrodynamic effects can be applied as such. The scientific foundations, equipment and applications of this technology are summarized in monographs [8-10], including those relevant for the nuclear power [5-7, 11-13]. Mathematical and physical modeling of methods and means enabling the processing of multicomponent media using cavitation effects are considered in $[8-10,14,15]$. These issues were further elaborated in [16-23].

\section{Elements of cavitation technology}

Physical model of cavitation hydrothermodynamic effects can be described by two main mechanisms: propagation of shock waves near collapsing cavitation microbubbles and impact action of $\mathrm{cu}^{-}$ mulative microstructures during their asymmetric collapse. In this case, high temperature (up to $15,000^{\circ} \mathrm{C}$ ) and high pressure (up to $1,000 \mathrm{MPa}$ ) fields are modeled. The flow rate of cumulative streams can reach $500 \mathrm{~m} / \mathrm{s}$. The phenomenon is accompanied by intense turbulent micro-mixing and mechanothermolysis of water resulting in the generation of $\mathrm{H}_{2}, \mathrm{O}_{2}, \mathrm{H}_{2} \mathrm{O}_{2}, \mathrm{HNO}_{3}, \mathrm{OH}^{-}$and free hydrogen bonds. Thus, the local area near the collapsing cavitation microbubble can be considered as a unique reactor for various reactions and unique industrial processes (cavitation technology) under normal external physical conditions [5, 8, 11, 23].

Possible solutions to the problems associated with the dissolution and further extraction of sediments from LRW storage facilities were analyzed with cavitation effects proposed as a possible option. Having considered the physical effect on the particles that occurs during the collapse of cavitation bubbles, as well as the changes in physical and chemical properties of water [23], the processes associated with the cavitation impact on the sediment particles present in aqueous solution could be described as follows. Cavitation pressure pulses during the bubble collapse viewed as spherical shock waves cause an irregular chaotic movement of microparticles, which precedes their destruction. Intensity of dispersion depends on the intensity of cavitation pressure pulses, micro-explosions at the stage of cavitation bubble collapse. Under these conditions, any asymmetry of microparticles causes the formation of an initial irregular structure of the velocity field resulting in its destruction. Smaller microparticles leave their outer surface, which exacerbates their initial asymmetry and accelerates the destruction process. Separated particles are also subject to destruction according to the above mechanism. The fineness degree is determined by the amount of energy released during bubble collapse. In this case, the dispersed phase particles appear to have larger surface where their interaction with chemicals and the dispersion medium (water) activated as a result of cavitation influences occurs. This results in the development of a heterogeneous disperse system being similar to the homogeneous one in terms of its structure [11,23].

Based on the above, application of activated water as a carrier phase in the solutions used to dissolve solid sediments is assumed to provide an increase in the dissolution efficiency without increasing the consumption of reagents and to reduce corrosion impacts on the walls of the tanks.

This article focuses on the capabilities of cavitation technologies applied to retrieve solid poorly soluble sediments from LRW storage tanks.

\section{Effect of cavitation on physical and chemical properties of water}

To assess the effectiveness of cavitation treatment, a number of physical and chemical parameters of water were considered: temperature, dissolved oxygen level (DOL), $\mathrm{pH}$, electrical conductivity, redox potential, etc. Dissolved oxygen analyzer MARK-201 and 4-parameter WaterTest device were used to measure these parameters

The water was treated in a cavitation mixer with a control and power unit [21]. Its engine power amounted to $1 \mathrm{~kW}$, the mixing chamber volume corresponded to $3 \cdot 10^{-4} \mathrm{~m}^{3}$. A two-bladed impeller with a wedge-shaped profile and wedge angles from 10 to $90^{\circ}$ was used as an actuating element. Rotating speed was increased to $14,000 \mathrm{rpm}$ resulting in the cavitation numbers of up to $\chi=0.05$. The control system allowed smooth adjustment of the rotor speed, as well as to maintain the desired number of revolutions regardless of the changing load and to record the processing time. Based on the preliminary study [22], a profile with a flank angle at the wedge tip of $20^{\circ}$ was chosen under this case study.

Activation of solid and liquid systems causing changes in their physical and chemical properties, reactivity, defective (impurity) structure, etc., may be attained by various external influences: weak and strong. Such effects include, in particular, mechanical, magnetic, ultrasonic treatment, radiation exposure (for example, irradiation with gamma rays and ion beams), as well as heat treatment. Activation methods can be divided into destructive samples as a whole (dispersion) and not destructive affecting only the defective structure.

Studies of hydromechanical water treatment (as a sufficiently strong effect) showed that 
subsequent activity of water is manifested both at the macroscale and at the microlevels (molecular and sub-molecular).

Hydrodynamic effects are caused by two mechanisms: propagation of shock waves near the collapsing cavitation microbubble and shock effects of cumulative microstructures with asymmetric collapse of cavitation microbubbles. Moreover, in this context, it does not matter which method was used to produce cavitation microbubbles. These basic mechanisms are accompanied by increasing temperatures and pressures near the bubble transforming the local area around it into a unique reactor for various reactions and processes, which was assumed as a basis for the cavitation method [8]. Today, cavitation water treatment is considered as least energy-consuming resulting in an energy consumption of about $0.65 \mathrm{~kW} / \mathrm{m}^{3}[8,23]$.

Considering the focus of this study, modes associated with maximum cavitation impact on water and optimal time of this impact based on the energy efficiency was viewed as of a key interest.

Based on experimental studies focused on the changes in the characteristics of distilled water after its cavitation treatment with a constant cavitation number $\chi=0.05$ and regression analysis methods, rational duration of cavitation treatment was calculated. Figure 1 presents the dynamics of changing redox water potential during this process. The graph is plotted according to experimental points averaged over 5-10 measurements; the relative error in determining the redox potential corresponds to $2 \%$. Changes in redox potential over the cavitation time occur exponentially and can be described by the following equation:

$$
\begin{gathered}
y=15,34 \exp (-x / 106,36)+15,34 \exp (-x / 106,39)+ \\
+149,24 \exp (-x / 21,28)+141,43
\end{gathered}
$$

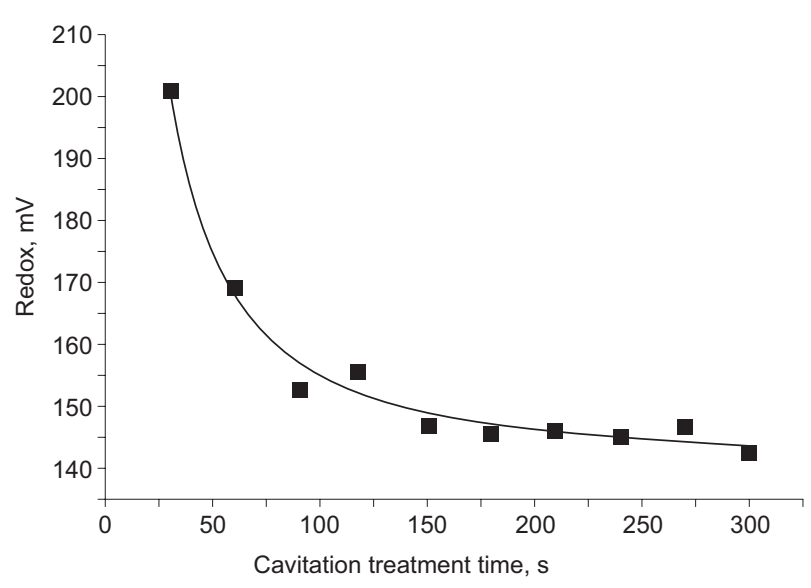

Figure 1. Time of cavitation treatment and redox potential of distilled water, given the redox potential of the initial distillate of $264 \mathrm{mV}$
If treatment time exceeds 150 seconds, redox potential practically does not change, thus, a time interval corresponding to a most intense redox change can be set (30-90 s). Due to the cavitation effect on water during this time period, redox potential decreases by $43 \%$, while the maximum decrease in it accounts for $47 \%$, i. e., in the range of $30-90 \mathrm{~s}$, the rate of changes in redox potential during cavitation is almost three times higher than the one corresponding to the range of 90-300 s. Table 1 presents the changes in water parameters following its cavitation treatment implemented given 100 and $65 \%$ filling of the mixer. Mixer filling by $65 \%$ was chosen randomly [22] to specify the effects produced by the interaction the free water surface with the atmosphere on the oxygen content, which in this case turned out to be insignificant. It was found that redox potential ranging from 200 to $128.5 \mathrm{mV}$ and electrical conductivity ranging from 3.0 to $14.5 \mathrm{Ohm}^{-1} / \mathrm{cm}$ can most significantly impact the solvent capacity of the treated water.

It was demonstrated [22-24] that water exposure to high pressure (up to 1,000 MPa) and temperature (up to $15,000^{\circ} \mathrm{C}$ ) fields formed due to the cavitation microbubbles collapse, results in the mechanothermolysis phenomenon: mechanochemical reactions are initiated in water resulting in the formation of $\mathrm{H}_{2}, \mathrm{O}_{2}, \mathrm{H}_{2} \mathrm{O}_{2}, \mathrm{HNO}_{3}, \mathrm{OH}^{-}$(during the recombination of radicals). At the same time, free hydrogen bonds are formed due to destruction, the phenomenon of chemiluminescence arises, due to which electrical conductivity, surface tension, oxygen content and $\mathrm{pH}$ of the treated water suffers some changes. Relaxation time for these properties amounting to up to $7-10$ days allows them to be used under various industrial processes on site or after transportation.

The considered phenomenon of water mechanolysis underlies specific properties and related phenomena occurring in water subjected to mechanical (hydrodynamic) impacts. Water modified as a result of hydromechanical treatment (also referred to as activated water) can intensify a number of processes by approximately $30 \%$ [8, 9, 23]. Under this study, "activated water" stands for a generally accepted concept of an active medium, i. e. a substance in which the distribution of particles (atoms, molecules, ions) by energy states is not equilibrium and the population is inverted for at least one pair of energy levels.

The described reactions explain the intense destruction of materials exposed to cavitation due to simultaneously occurring cavitation erosion and chemical corrosion, which are closely interrelated. Thus, under the influence of cavitation in an aqueous solution, various chemical reactions can occur. Their cavitation initiation is reduced to ionization 
Table 1. Physical and chemical characteristics of water before and after cavitation treatment

\begin{tabular}{|c|c|c|c|c|c|c|c|c|c|c|}
\hline \multirow{5}{*}{$\begin{array}{l}\text { Filling of } \\
\text { the CT-mixer } \\
\text { capacity V, \% }\end{array}$} & \multicolumn{2}{|c|}{$T,{ }^{\circ} \mathrm{C}$} & \multicolumn{2}{|c|}{ DOL, \% sat } & \multicolumn{2}{|c|}{$\mathrm{S}, 0 \mathrm{hm}^{-1} / \mathrm{m}$} & \multicolumn{2}{|c|}{ pH } & \multicolumn{2}{|c|}{$E, \mathrm{mV}$} \\
\hline & $\alpha=10^{\circ}$ & $\alpha=20^{\circ}$ & $\alpha=10^{\circ}$ & $\alpha=20^{\circ}$ & $\alpha=10^{\circ}$ & $\alpha=20^{\circ}$ & $\alpha=10^{\circ}$ & $\alpha=20^{\circ}$ & $\alpha=10^{\circ}$ & $\alpha=20^{\circ}$ \\
\hline & \multicolumn{10}{|c|}{ Water parameters before treatment } \\
\hline & \multicolumn{2}{|c|}{20.7} & \multicolumn{2}{|c|}{101.2} & \multicolumn{2}{|c|}{3.0} & \multicolumn{2}{|c|}{5.4} & \multicolumn{2}{|c|}{200} \\
\hline & \multicolumn{10}{|c|}{ Water parameters after treatment } \\
\hline 100 & 40.5 & 32.6 & 85.1 & 96.65 & 14.5 & 6 & 5.65 & 5.45 & 133 & 168.5 \\
\hline 65 & 34.6 & 27.2 & 87.65 & 95.7 & 5.5 & 13 & 6.0 & 5.7 & 128.5 & 147 \\
\hline
\end{tabular}

Note: DOL - dissolved oxygen level; $\alpha$ - apex angle of the wedge-shaped cavitator inside the CT-mixer; $E$ - redox potential; $\mathrm{S}$ - electrical conductivity.

and excitation of water molecules, formation of active gases, as well as to dissociation of water molecules. Each of these processes takes about 1014 seconds [24]. Final stage of bubble collapse can last for approximately $10^{-9}-10^{-8} \mathrm{~s}$.

In the cavitation cavity, the aforesaid processes occur along with radical transformation reactions involving chemically active gases and recombination of radicals over a period of $10^{-7}-10^{-6} \mathrm{~s}$. Due to these processes, after the cavitation bubble collapses, the products of radical decomposition of $\mathrm{H}_{2} \mathrm{O}$ molecules and recombination of radicals detected by the spin trap method pass into solution resulting in the accumulation of molecular $\mathrm{O}_{2}, \mathrm{H}_{2} \mathrm{O}_{2}$, and other compounds in water.

The high rate of reactions indicates that they occur immediately in the cavitation destruction zone, accelerating cavitation erosion, which is extremely important during the operation of various hydro and power equipment, as well as under the dispersion of various materials (for example, cement stone). Water characterized by such properties promotes the dissolution of poorly soluble materials [8, 23].

\section{Studied physical and chemical properties of pulp}

Pulps formed during LRW storage are characterized with relatively high activity level and a heterogeneous composition. A quite comprehensive discussion of the mechanisms providing for the formation of solid poorly soluble sediments and their composition can be found in [25-27].

To simulate the neutralization process, solutions of the following composition $\left(\mathrm{g} / \mathrm{dm}^{3}\right)$ were used: acidic $\left(\mathrm{HNO}_{3}-30 ; \mathrm{Al}-3.0 ; \mathrm{Fe}-10.0 ; \mathrm{Cr}-2.0\right.$; $\mathrm{Mn}-3.0 ; \mathrm{Ni}-2.0 ; \mathrm{Ca}-0.7 ; \mathrm{U}-10.0)$ and alkaline $\left(\mathrm{NaOH}-200 ; \mathrm{SiO}_{2}-3.0\right)$. Calculations showed that $\mathrm{pH}$ of 11 is attained if the volume ratio between acidic and alkaline solutions corresponds 1:0.4. In this case, a precipitate of the following composition is formed: hematite $\left(\mathrm{Fe}_{2} \mathrm{O}_{3}\right)-31 \%$ vol ;; andradite $\left(\mathrm{Ca}_{3} \mathrm{Fe}_{2} \mathrm{Si}_{3} \mathrm{O}_{12}\right)-9.4 \%$; gibbsite $\left(\mathrm{Al}(\mathrm{OH})_{3}\right)-23 \%$; sodium diuranate $\left(\mathrm{Na}_{2} \mathrm{U}_{2} \mathrm{O}_{7} \cdot 6 \mathrm{H}_{2} \mathrm{O}\right)-12.9 \%$; chromium oxide $\left(\mathrm{Cr}_{2} \mathrm{O}_{3}\right)-9.8 \%$; nepheline $\left(\mathrm{NaAlSiO}_{4}\right)-$ $0.4 \%$; manganese dioxide $\left(\mathrm{MnO}_{2}\right)-8.1 \%$; bunsenite $(\mathrm{NiO})-4.6 \%$. The total volume of sediment formed during the neutralization of $1 \mathrm{~m}^{3}$ of model waste amounts to $8.13 \mathrm{dm}^{3}$. Sediment of this mineral composition was used in calculations simulating chemical transformations occurring during the long-term storage of pulps [28].

Thermodynamic calculations (Figures 2 and 3) give an idea of possible phase composition of the sediment produced at different temperatures (from 80 to $180^{\circ} \mathrm{C}$ ). Alterations in the composition of the precipitate depending on the pulp storage time in the tanks was modeled by increasing the volume of decantate interacted with the precipitate $(S: L=0.08: 25$ and $S: L=0.08: 1000)$. The temperature range and phase ratios were chosen taking into account the conditions for upper and lower pulp layer formation in the tank. The results obtained illustrate with a high degree of probability the distribution of pulp components and explain the unevenness of their extraction [29, 30].

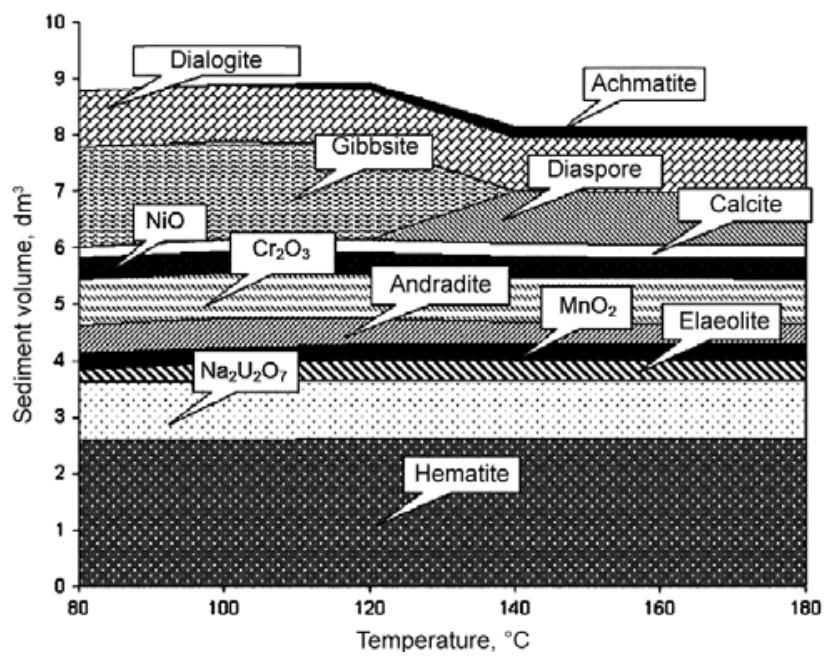

Figure 2. Mineral composition of model sediments interacting with $25 \mathrm{~m}^{3}$ of model solution at a temperature of $80-180^{\circ} \mathrm{C}$ (upper layer of pulp) [28] 


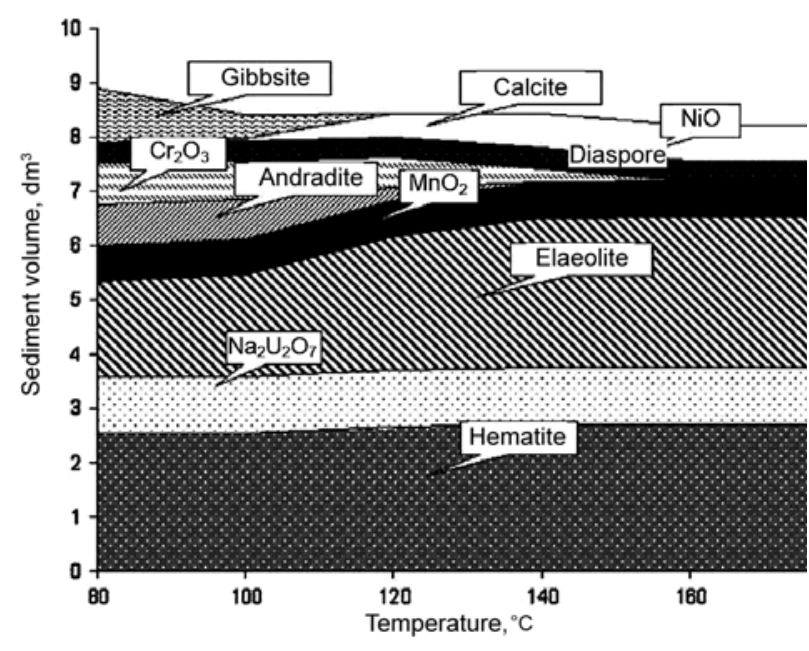

Figure 3. Mineral composition of model sediments interacting with $1000 \mathrm{~m}^{3}$ of model solution at a temperature of $80-180^{\circ} \mathrm{C}$ (lower layer of pulp) [28]

In aluminate solutions silicon is available as $\left[\mathrm{SiAlnO}_{2(\mathrm{n}+1)}(\mathrm{OH})_{\mathrm{m}}\right]^{(\mathrm{n}+\mathrm{m})-}$ ion formed as follows:

$\mathrm{SiO}_{2}(\mathrm{OH})_{2}^{2-}+n \mathrm{AlO}_{2} \leftrightarrow\left[\mathrm{SiAl}_{n} \mathrm{O}_{2(n+1)}(\mathrm{OH})_{m}\right]^{(n+m)-}+(2-m) \mathrm{OH}^{-}$.

In aluminum production, silicon compounds are removed from aluminate solutions by means of their 2-3 hour-long sedimentation at a temperature of $150-170^{\circ} \mathrm{C}$ resulting in sodium hydroaluminosilicate sediment $n \mathrm{Na}_{2} \mathrm{OAl}_{2} \mathrm{O}_{3}(1,4 \ldots 2,0) \mathrm{SiO}_{2} x \mathrm{H}_{2} \mathrm{O}$. In this case, the rate of "desiliconization" of aluminate solutions depends on their temperature and the mixing intensity.

In [31, experiment 3], porous layer structure of a solid phase was destroyed and dissolved by alternate treatment with a sodium hydroxide containing solution (100 g/l) and a solution containing $40 \mathrm{~g} / \mathrm{l}$ of nitric acid and $20 \%$ vol. caprolactam production waste (CPW). After each solution was applied, the solid phase was washed with water. After 6 hours of treatment the resulting suspension was subjected to a 1-day long sedimentation. Then the volume of the solid phase was measured. During the last, 11th pulp treatment with a solution containing nitric acid and CPW, the solid phase-solution mixing time was increased to 18 hours.

Under the next experiment [31, experiment 4] based on experiment 3 , conventional water was replaced by cavitation-activated water. Two aliquots of about $3 \mathrm{ml}$ were taken. One aliquot was filled with $50 \mathrm{ml}$ of pure water, another - with $50 \mathrm{ml}$ of cavitation-activated water. The pulp was treated without heating $\left(\mathrm{t}=22^{\circ} \mathrm{C}\right)$ accompanied by intense mixing with compressed air for 6 hours, followed by 18 hour-long settling. Visual inspection showed that in case of pure-water aliquot treatment, large fragments of pulp remained in the mixture: uneven solid phase erosion with some $15 \%$ of it has passed into suspension. After settling, the phase boundary was blurred. Consistency of settled sediment corresponds to the one of liquid clay.

Under aliquot treatment with cavitation-activated water, large fragments appeared to be significantly smaller: about $60 \%$ of the solid phase passed into the suspension. The phase boundary was clearly visible. Sediment appeared to be fundamentally different from the previous one: its volume was larger, had lower density and consistency. At the point of solid phase erosion, pulp components interacted with the active components of cavitation-activated water, as a result of which the pulp particles have swollen. This evidences a more intense physical effect of cavitation-activated water on pulp particles.

Experiment 4 showed that the yield of pulp components in the solution amounts to $56.03 \%$ for $\mathrm{Al}$ and to $60.72 \%$ for $\mathrm{SiO}_{2}$, whereas common treatment methods yielded 35.6 and $34.39 \%$, respectively (Table 2, Figures 4 and 5).

Table 2. Distribution of aluminosilicate layer components of the solid phase between the solutions applied for its treatment (experiments 3, 4) [31]

\begin{tabular}{|c|c|c|c|c|c|}
\hline \multirow{3}{*}{$\begin{array}{l}\text { Treat- } \\
\text { ment } \\
\text { stage }\end{array}$} & \multirow{3}{*}{$\begin{array}{l}\text { Composition of } \\
\text { pulp treatment } \\
\text { solutions }\end{array}$} & \multicolumn{4}{|c|}{ Degree of transition into the solution } \\
\hline & & \multicolumn{2}{|c|}{ Experiment 3} & \multicolumn{2}{|c|}{ Experiment 4} \\
\hline & & $\mathrm{Al}$ & $\mathrm{SiO}_{2}$ & $\mathrm{Al}$ & $\mathrm{SiO}_{2}$ \\
\hline 1 & $100 \mathrm{~g} / \mathrm{l} \mathrm{NaOH}$ & 2.52 & 1.81 & 5.79 & 4.34 \\
\hline 2 & $\mathrm{H}_{2} \mathrm{O}$ & 2.04 & 0.70 & 2.36 & 0.85 \\
\hline 3 & $\mathrm{HNO}_{3}+\mathrm{CPW}$ & 1.39 & 8.57 & 2.50 & 15.43 \\
\hline 4 & $\mathrm{H}_{2} \mathrm{O}$ & 0.56 & 0.57 & 0.64 & 0.64 \\
\hline 5 & $100 \mathrm{~g} / \mathrm{l} \mathrm{NaOH}$ & 8.88 & 2.74 & 16.87 & 6.30 \\
\hline 6 & $\mathrm{H}_{2} \mathrm{O}$ & 5.54 & 0.94 & 6.34 & 1.15 \\
\hline 7 & $\mathrm{HNO}_{3}+\mathrm{CPW}$ & 1.22 & 8.65 & 2.01 & 14.96 \\
\hline 8 & $\mathrm{H}_{2} \mathrm{O}$ & 0.32 & 1.01 & 0.36 & 1.14 \\
\hline 9 & $100 \mathrm{~g} / \mathrm{l} \mathrm{NaOH}$ & 4.72 & 2.57 & 9.48 & 5.04 \\
\hline 10 & $\mathrm{H}_{2} \mathrm{O}$ & 6.60 & 1.28 & 7.34 & 1.68 \\
\hline \multirow[t]{2}{*}{11} & $\mathrm{HNO}_{3}+\mathrm{CPW}$ & 1.36 & 5.54 & 2.31 & 9.19 \\
\hline & Total & 35.6 & 34.39 & 56.03 & 60.72 \\
\hline
\end{tabular}

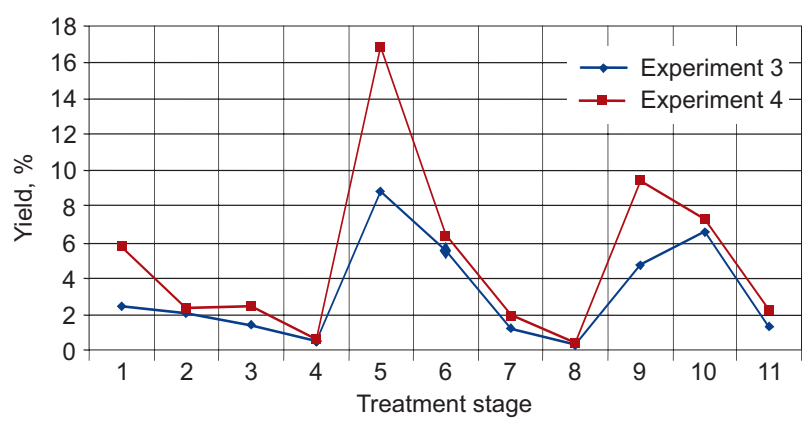

Figure 4. Al yield into solution [31] 


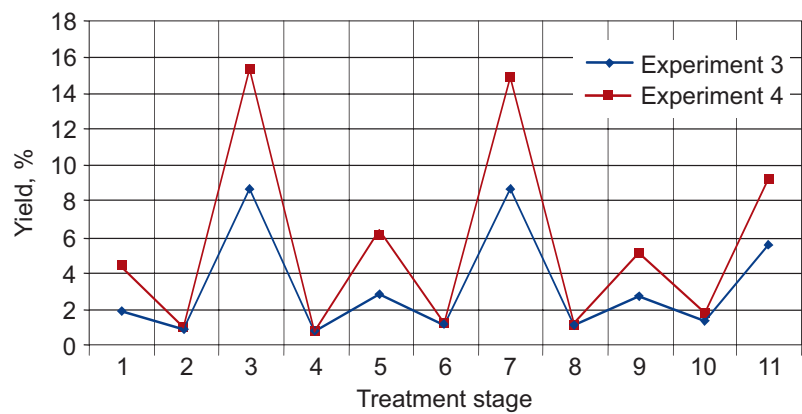

Figure 5. $\mathrm{SiO}_{2}$ yield into solution [31]

\section{Conclusion}

The considered method suggesting the destruction of pulp components during sediment erosion by solutions based on cavitation-activated water enables more efficient retrieval of sediments (HLW LRW) accumulated in storage tanks providing for no increased concentration of chemical reagents and temperatures. This method avoids the accumulation of fissile materials and reduces the corrosion load on structural elements of storage facilities. It has been experimentally established that the use of cavitation-activated water can almost double the yield of poorly soluble pulp components up to $56.03 \%$ (for $\mathrm{Al}$ ) and up to $60.72 \%$ (for $\mathrm{SiO} 2$ ) compared to conventional treatment (35.6\% and 34 , $39 \%$, respectively).

It has been established that the relaxation time of the modified water properties falls in the range between 1 and 500 hours given various conditions. Thus, it can be used in different industrial processes, including as a carrier phase in the dissolution of the main pulp components.

Water exposure to high pressures (up to $1,000 \mathrm{MPa}$ ) and temperatures (up to $15,000{ }^{\circ} \mathrm{C}$ ) due to the collapse of cavitation microbubbles, results in a mechanothermolysis phenomenon: mechanochemical reactions are initiated in water, free hydrogen bonds are formed as a result of destruction, which in turn entails alterations in electrical conductivity, oxygen content, $\mathrm{pH}$ of the medium and the redox potential. Thus, this phenomenon can be quite efficiently applied for water treatment purposes in the energy sector and other industries.

\section{References}

1. Ukaz Prezidenta Rossiyskoy Federatsii «Ob utverzhdenii prioritetnykh napravleniy razvitiya nauki, tekhnologiy i tekhniki v Rossiyskoy Federatsii i perechnya kriticheskikh tekhnologiy Rossiyskoy Federatsii» ot 7 iyulya 2011 goda No 899 [Decree of the President of the Russian Federation "On approval of priority areas for the development of science, technology and technology in the Russian Federation and the list of critical technologies of the Russian Federation" dated July 7, 2011, No. 899].

2. Dorofeyev A. N. O khode rabot po razvitiyu normativno-pravovoi bazy $\mathrm{v}$ oblasti obrashcheniya $\mathrm{s}$ radioaktivnymi otkhodami [On the progress of development of the regulatory framework in the field of radioactive waste management]. Radioaktivnye othody - Radioactive Waste, 2019, no. 3 (8), pp. 6-13. DOI:10.25283/2587-9707-2019-3-6-13.

3. Strategiya razvitiya yadernoj energetiki Rossii do 2050 goda i perspektivy na period do 2100 goda [Strategy for nuclear power development in Russia until 2100]. Approved by the order of Scientific Technical Council's Presidium of the State Corporation Rosatom on the 26th of December, 2018. Moscow, 62 p.

4. Bolshov L. A., Linge I. I. O soglasovanii etapov razvitiya atomnogo energopromyshlennogo kompleksa i sistemy obrashcheniya s RAO [On the coordination of the stages of development of the atomic energy industrial complex and the radioactive waste management system]. Radioaktivnye othody Radioactive Waste, 2019, no. 3 (8), pp. 34-41. DOI: 10.25283/2587-9707-2019-3-14-27.

5. Kulagina T. A., Kulagin V. A., Moskvichev V. V., Popkov V. A. Primeneniye kavitatsionnoy tekhnologii $\mathrm{v}$ protsessakh obrashcheniya $\mathrm{s}$ otrabotavshim yadernym toplivom [The use of cavitation technology in the processes of handling spent nuclear fuel]. Ekologiya i promyshlennost' Rossii - Ecology and Industry of Russia, 2016, vol. 20, no. 10, pp. 4-10. DOI: 10.18412 / 1816-0395-2016-10-4-10.

6. Kulagina T. A., Matyushenko A. I., Kozin O. A. i dr. Upravleniye promyshlennymi i osobo opasnymi otkhodami [Management of industrial and especially hazardous waste]. Ed. A. I. Matyushenko. - MoscowSmolensk, Magenta Publ., 2010. 480 p.

7. Kulagina T. A., Kulagin V. A., Matyushenko A. I. Tekhnosfernaya bezopasnost' $v$ yadernoy energetike [Technosphere Safety in Nuclear Energy]. Krasnoyarsk, Grotesque Publ., SFU, 2014. 286 p.

8. Ivchenko V. M., Kulagin V. A., Nemchin A. F. Kavitatsionnaya tekhnologiya [Cavitation technology]. Ed. Acad. G. V. Logvinovich. Krasnoyarsk, KSU Publ., 1990. $200 \mathrm{p}$.

9. Demidenko N. D., Kulagin V. A., Shokin Yu. I. Modelirovaniye i vychislitel'nyye tekhnologii raspredelennykh system [Modeling and computing technology of distributed systems]. Ed. Corr. RAS A. M. Fedotov. Novosibirsk, Nauka Publ., 2012. 424 p.

10. Demidenko N. D., Kulagin V. A., Shokin Yu. I., Li F.-Ch. Teplomassoobmen $i$ superkavitatsiya [Heat and mass transfer and supercavitation]. Novosibirsk, Nauka Publ., 2015. 436 p. 
11. Kulagina T. A., Kozin O. A., Popkov V. A. $\mathrm{Ob}-$ rashcheniye s radioaktivnymi otkhodami [Radioactive waste management]. Krasnoyarsk, Grotesque Publ., Siberian Federal University Publ., 2018. 183 p.

12. Kulagin V., Kulagina T., Nikiforova E., Prikhodov D., Shimanskiy A., Li F.-Ch. Inclusion of liquid radioactive waste into a cement compound with an additive of multilayer carbon nanotubes. IOP Conf. Series: Earth and Environmental Science, 2019, 227, 052030, pp. 1-12. DOI: $10.1088 / 1755-1315 / 227 / 5 / 052030$.

13. Kulagina T.A., Kulagin V.A., Popkov V.A. Compounding of spent nuclear fuel. J. Sib. Fed. Univ. Eng. technol., 2016, no. 9 (2), pp. 280-295. DOI: 10.17516/1999-494X-2016-9-2-280-295.

14. Kulagin V. A., Vil'chenko A. P., Kulagina T. A. Modelirovaniye dvukhfaznykh superkavitatsionnykh potokov [Modeling of two-phase supercavitation flows]. Ed. V. I. Bykov. Krasnoyarsk, CPI KSTU Publ., $2001.187 \mathrm{p}$.

15. Kulagin V.A., Moskvichev V. V., Makhutov N. A., Markovich D. M., Shokin Yu. I. Problemy fizicheskogo i matematicheskogo modelirovaniya $\mathrm{v}$ oblasti gidrodinamiki bol'shih skorostej na eksperimental'noj baze Krasnoyarskoj GES [Physical and mathematical modeling in the field of high-velocity hydrodynamics in the experimental base of the Krasnoyarsk hydroelectric plant]. Vestnik Rossijskoj akademii nauk - Herald of the Russian Academy of Sciences, 2016, vol. 86, no. 6, pp. 454-465. DOI: $10.1134 / \mathrm{S} 1019331616060034$. (IF 0,596, Q1).

16. Zhi-Ying Zh., Qian L., Lu W., Li-Ming Y., WeiHua C., Kulagin V. A., Hui L., Feng-Chen L. Numerical study on the effect of steam extraction on hydrodynamic characteristics of rotational supercavitating evaporator for desalination [J]. Desalination, 2019, no. 455, pp. 1-18. DOI.ORG/10.1016/ j.desal.2018.12.012 (IF 6,603, Q1).

17. Zheng Zh., Li Q., Li F., Kulagin V.A. Numerical study on parameter selection for steam extraction of rotational supercavitating evaporator. Journal of University of Chinese Academy of Sciences, 2016, no. 33 (2), pp. 247-252. DOI: 10.7523/ j.issn.2095-6134.2016.02.016.

18. Zheng Z. Y., Qian L., Feng-Chen L., Kulagin A. V. Numerical study on the characteristics of natural supercavitation by planar symmetric wedgeshaped cavitators for rotational supercavitating evaporator. Sci. China Tech Sci., 2015, no. 58, pp. 1-12. DOI: $10.1007 / \mathrm{s} 11431-015-5827-\mathrm{y}$.

19. Likhachev D. S., Feng-Chen L., Kulagin V. A. Experimental study of thermohydrodynamic characteristics of a rotational supercavitating evaporator for desalination. Sci. China. Tech. Sci,. 2014, no. 57, pp. 2115-2130. DOI: 10.1007/s11431-014-5631-0.
20. Kulagin V. A., P'yanykh T. A. Modeling of processes in supercavitation evaporator with consideration of thermodynamic effects. Chemical and Petroleum Engineering, 2014, vol. 50, no. 1-2, pp. 24-29. DOI: 10.1007/s10556-014-9848-3.

21. Kulagin V. A. Superkavitacionnyj mikser. Gidrodinamika bol'shih skorostej. [Super cavitation mixer. Hydrodynamics of high speeds]. Krasnoyarsk, KrPI Publ., 1992. Pp. 134-140.

22. Kulagin V. A., Sapoghnikova E. S., Stebeleva O. P. Features of Influence of Cavitation Effects on the Physicochemical Properties of Water and Wastewater. J. Sib. Fed. Univ. Eng. Technol., 2014, no.7(5), pp. 605-614.

23. Kulagin V. A. Metody i sredstva tekhnologicheskoy obrabotki mnogokomponentnykh sred sispol'zovaniyem effektov kavitatsii [Methods and means of technological processing of multicomponent media using cavitation effects]. Diss. ... Dr. tech. sciences. Krasnoyarsk, 2004. $406 \mathrm{p}$.

24. Margulis M. A. Zvukokhimicheskiye reaktsii i sonolyuminestsentsiya [Sound chemical reactions and sonoluminescence]. Moscow, Khimiya Publ., 1986. 288 p.

25. Tananayev I. G., Myasoyedov B. F. Khimicheskoye povedeniye plutoniya $v$ shchelochnykh otkhoda$k h$ : formy sushchestvovaniya, redoks-reaktsii i strukturnyye prevrashcheniya [Chemical behavior of plutonium in alkaline waste: forms of existence, redox reactions and structural transformations]. Moscow, Institute of Geochemistry and Analytical Chemistry RAS im. V. I. Vernadskogo Publ., 2002. 356 p.

26. Yermolayev V. M., Zakharova Ye. V., Mironenko M.V. Izmeneniye sostava i svoystv radioaktivnykh pul'p v protsesse dlitel'nogo khraneniya $\mathrm{v}$ yemkostyakh [Changes in the composition and properties of radioactive pulps during long-term storage in containers]. Radiokhimiya - Radiochemistry, 2006, vol. 47, no. 3, pp. 374-379.

27. Shilov V. P., Fedoseyev A. M. Rastvorimost' Pu (IV) v slaboshchelochnykh sredakh (pH 9-14) v prisutstvii silikat ionov [Solubility of $\mathrm{Pu}$ (IV) in slightly alkaline media (pH 9-14) in the presence of silicate ions]. Radiokhimiya - Radiochemistry, 2003, vol. 45, no. 5, pp. 441-444.

28. Yermolayev V. M. Fiziko-khimicheskiye osnovy pererabotki geterogennykh otkhodov (pul'p) radiokhimicheskikh proizvodstv [Physicochemical fundamentals of the processing of heterogeneous waste (pulp) of radiochemical industries]. Abstract. diss. ... cand. tech. sciences. Moscow, 2007. 26 p.

29. Yermolayev V. M., Zakharova Ye.V., Revenko Yu. A., Sorokin Yu. P., Kostin E. M. Issledovaniye khimicheskogo i fazovogo sostava radioaktivnoy pul'py $\mathrm{v}$ yemkostyakh-khranilishchakh [Investigation of the chemical and phase composition of radioactive pulp in storage tanks]. Atomnaya energiya - Atomic Energy, 1997, vol. 83, no. 5, pp. 344-348. 
30. Yermolayev V. M., Zakharova Ye. V., Revenko Yu. A., Sorokin Yu. P., Kostin E. M. Khimicheskoye modelirovaniye khraneniya radioaktivnoy pul'py $\mathrm{v}$ yemkostyakh [Chemical modeling of storage of radioactive pulp in containers]. Atomnaya energiya - Atomic Energy, 1997, vol. 83, no. 5, pp. 349-353.
31. Kozin O. A. Metody i sredstva povysheniya ekologicheskoy bezopasnosti obrashcheniya s otkhodami yaderno-energeticheskogo tsikla [Methods and means of improving the environmental safety of waste management of the nuclear energy cycle.]. Abstract. diss.... cand. tech. sciences. Krasnoyarsk, 2011. 19 p.

\section{Information about the authors}

Kulagina Tatyana Anatolyevna, Doctor of Technical Sciences, Professor, Head of the Department of Technosphere and Environmental Safety, Federal State Autonomous Educational Institution of Higher Education "Siberian Federal University" (79, Svobodny pr., Krasnoyarsk, 660041, Russia), e-mail: tak.sfu@gmail.com.

Kulagin Vladimir Alekseevich, Doctor of Technical Sciences, Professor, Head of the Department of Heat Engineering and Hydro-Gasdynamics, Federal State Autonomous Educational Institution of Higher Education "Siberian Federal University" (79 Svobodny pr., Krasnoyarsk, 660041, Russia), e-mail:v.a.kulagin@ mail.ru.

\section{Bibliographic description}

Kulagina T. A., Kulagin V. A. Aluminosilicate Sediment Dissolution in Liquid Radioactive Waste Storage Facilities. Radioactive waste, 2020, no. 2 (11), pp. 75-84.(In Russian). DOI: 10.25283/2587-9707-2020-2-75-84. 